\title{
Can We Predict How Earthworm Effects on Plant Growth Vary with Soil Properties?
}

\author{
Kam-Rigne Laossi, ${ }^{1,2}$ Thibaud Decaëns, ${ }^{1}$ Pascal Jouquet, ${ }^{3}$ and Sébastien Barot ${ }^{4}$ \\ ${ }^{1}$ Laboratoire d'Ecologie, UPRES EA 1293 ECODIV, FED SCALE, UFR Sciences et Techniques, Université de Rouen, \\ 76821 Mont Saint Aignan cedex, France \\ ${ }^{2}$ Agronomy Department, Centre R\&D Nestlé Abidjan, 01 BP 11356 Abidjan 01, Cote D’Ivoire \\ ${ }^{3}$ Bioemco (UMR 7618)_IWMI, SFRI, Dong Ngac, Tu Liem, Hanoï, Vietnam \\ ${ }^{4}$ Bioemco (UMR 7618), Site Ecole Normale Supérieure, 46 rue d'Ulm, 75230 Paris cedex 05, France
}

Correspondence should be addressed to Kam-Rigne Laossi, kamrigne.laossi@rd.nestle.com

Received 26 June 2009; Revised 11 December 2009; Accepted 23 January 2010

Academic Editor: Natchimuthu Karmegam

Copyright (C) 2010 Kam-Rigne Laossi et al. This is an open access article distributed under the Creative Commons Attribution License, which permits unrestricted use, distribution, and reproduction in any medium, provided the original work is properly cited.

\begin{abstract}
Earthworms are usually assumed to enhance plant growth through different mechanisms which are now clearly identified. It is however difficult to determine their relative importance, and to predict a priori the strength and direction of the effects of a given earthworm species on a given plant. Soil properties are likely to be very influential in determining plant responses to earthworm activities. They are likely to change the relative strength of the various mechanisms involved in plant-earthworm interactions. In this paper, we review the different rationales used to explain changes in earthworm effect due to soil type. Then, we systematically discuss the effect of main soil characteristics (soil texture, OM, and nutrient contents) on the different mechanisms allowing earthworm to influence plant growth. Finally, we identify the main shortcomings in our knowledge and point out the new experimental and meta-analytical approaches that need to be developed. An example of such a meta-analysis is given and means to go further are suggested. The result highlights a strong positive effect size in sandy soil and a weakly negative effect in clayey soil.
\end{abstract}

\section{Introduction}

Earthworms are among the most important detritivores in terrestrial ecosystems in terms of biomass and activity [1]. They are known to affect plant growth through five main mechanisms [2, 3]: (1) the enhancement of soil organic matter mineralization, (2) the production of plant growth regulators via the stimulation of microbial activity, (3) the control of pests and parasites, (4) the stimulation of symbionts, and (5) the modifications of soil porosity and aggregation, which induce changes in water and oxygen availability to plant roots. Although these mechanisms are well identified, it is difficult to determine their relative influence [4] and to predict the impact of a given earthworm species on a given plant species.

In a recent review, Brown et al. [2] proposed that the response of plants to earthworms should depend on soil properties such as texture, mineral nutrient levels, and organic matter content. However, most studies tackling earthworm effects on plant growth used soils containing more sand than clay (Brown et al. [2] and see Table 1). Comparatively, few studies [5-7] have tested in the same experiment earthworm effects on plant growth using different soils. Doube et al. [5] showed that the endogeic Aporrectodea trapezoides may increase wheat growth in sandy soils but may have no significant effect with a clayey substrate. They also found that the growth and grain yield of barley were both increased by A. trapezoides and Aporrectodea rosea in the sandy soil but reduced in the clayey one. On the contrary, Laossi et al. [7] showed that Lumbricus terrestris increased the shoot and total biomasses of Trifolium dubium in a clayey and nutrient-rich soil but not in a sandy and nutrient-poor one. The hypothesis that earthworm effects on plant growth should vary with soil type is based on two main reasons. (1) Soil properties may inhibit or stimulate some of the mechanisms through which earthworms tend to increase 
plant growth. (2) If earthworms are able to alleviate limiting factor for plant growth, their impacts are expected to be weak in soils where the factor is not limiting. According to this rationale, the main mechanism through which earthworms affect plants should depend on soil type and in some soils earthworms might have no detectable or negative effect on plant growth.

\section{How Soil Properties Should Modulate Earthworm Effects on Plant Growth?}

Below, we go through the different mechanisms listed above and try to determine how soil properties should modulate their effect on plant growth.

(1) Earthworm activities usually have a positive impact on the mineralization of soil organic matter [8]. This effect is assumed to be a consequence of plant litter fragmentation and incorporation into the soil, as well as of the selective stimulation of microbial activity $[9,10]$. Hence earthworms may enhance the release of nutrients that become available to plants and thus increase plant growth when they allow higher nutrient uptake than nutrient leaching $[11,12]$. Anecic and endogeic earthworms have different feeding habits and affect differently soil organic matter composition and distribution [13]. Anecic earthworms feed on plant litter at the soil surface and tend to live in semipermanent vertical burrows while endogeic earthworms are active within the soil profile where they feed on soil organic matter [14]. This can lead to different effect on plant growth [15-17] which could also vary with soil properties such as organic matter and nutrient contents [18]. However, this rationale only holds if nutrients are limiting plant growth, that is, in soils where nutrients are poorly available. In contrast, in nutrient-rich soils, plants are less limited by the availability of mineral nutrients and earthworm-mediated mineralization should have less or no influence on plant growth [2]. Water is between the factors that limit plant growth and earthworms have been found to increase drought stress in plants [19]. This effect should be stronger in sandy soil which retains less water than in a clayey one.

(2) Earthworms affect plant growth through modifications of soil structure. They tend to increase soil porosity and the stability of organomineral aggregates by creating burrows and organomineral casts at different places within the soil profile $[20,21]$. This effect is assumed to enhance plant growth in most situations [2] although opposite effects have also been reported [22]. It is difficult to predict how soil texture will modulate these effects. In clayey soils, earthworm might lead to very stable structures which could in turn strongly influence plant growth. This influence could be positive if the casts produced by earthworms do not lead to soil compaction [22], or negative with a physical protection of organic matter that impedes the release of mineral nutrients. In sandy soils, structures created by earthworms are more fragile [23] but more mineral nutrients can be released since the soil organic matter is less protected.

(3) Earthworm effects on plant growth via the release of plant growth regulators may be modulated by soil properties through several mechanisms, but here again the outcome is difficult to be predicted. First, plant growth regulators are though to be released by bacteria [24] and may be differently available depending on the levels of microbial activity in the soil. Sandy soils and soil with low organic matter contents usually have lower microbial biomasses and low potential for plant growth regulator production [25]. Thus, in such soils, earthworm effects via production of plant growth regulator could lead to weak effects on plant growth. Second, soil texture and soil organic matter could also affect the short-term availability of the produced phytohormones. For instance, clays and organic matter are known to adsorb organic molecules [26] and could reduce plant growth regulator availability to plants and weaken earthworm effect on plant growth.

(4) Earthworms are known to alleviate the negative effect of some parasites on plant growth by reducing strongly their density [27], ingesting and killing some pathogens in their intestine, or producing unfavourable conditions in cast material or tunnel lining [28]. This kind of mechanism may be influential for plant growth, especially in soil properties (such as moisture and temperature) that allow the development of abundant parasite populations. We can thus expect more parasites and greater negative effect of earthworms on them in a clayey soil.

(5) Similarly, earthworms can increase plant growth through the stimulation of symbionts or the increase in the contact between plants and symbionts [29]. Besides, if symbionts such as mycorrhizae provide nutrients to plants, symbiont-mediated earthworm effect (as their effect through mineralization) on plants should be more marked in poor soils than in rich soils where mineral resources are already available.

Taken together, these elements show that earthworm effects on plants vary with soil type but that it is difficult to predict the direction and the intensity of these variations. To make relevant predictions, we need to develop studies comparing in the same experiment earthworm effects on plants under different soil conditions. It is also necessary to set up meta-analyses using data of previous earthwormsplants studies. We provide below an example of what could be done through computing the effect size of earthworms on plant growth using meta-analysis with the data of the studies listed in Table 1.

\section{How Can We Go Further?}

To determine how earthworms effects on plant growth change with soil properties a first approach would be to compare earthworm-induced effects in different soils but in the same experimental conditions (same plant and earthworm species, same watering protocol, same greenhouse, etc.). Such experiments have been so far very scarce (but see [5-7]). To help predicting earthworm effects on plant growth in different soil types one could also use the "allminus-one" tests proposed by Brown et al. [2]. In such experiments, only one factor such as mineral nutrition [4] or a root parasite [27] is limiting plant growth so 
TABLE 1: References included in the survey of $\mathrm{C}$ and $\mathrm{N}$ contents in soil and the soil texture used in earthworm effects on plant growth.

\begin{tabular}{|c|c|c|c|c|c|c|}
\hline References & Soil classification & Soil texture & $\mathrm{N}$ total & Clay & Sand & C Total \\
\hline Aira and Plearce 2009 & $\begin{array}{l}\text { John Innes potting } \\
\text { compost no. } 2\end{array}$ & Loamy compost & $?$ & $?$ & $20 \%$ & $?$ \\
\hline Blouin et al. 2005 & Ultisol & Sandy soil & $0.05 \%$ & $6 \%$ & $78 \%$ & $0.91 \%$ \\
\hline Blouin et al. 2006 & Ultisol & Sandy soil & $0.05 \%$ & $6 \%$ & $78 \%$ & $0.91 \%$ \\
\hline Blouin et al. 2007 & Ultisol & Sandy soil & $0.05 \%$ & $6 \%$ & $78 \%$ & $0.91 \%$ \\
\hline Bonkowski et al. 2001 & $?$ & Loam soil + sand & $0.1 \%$ & $?$ & $>50 \%$ & $1.52 \%$ \\
\hline Clapperton et al. 2001 & Chernozem & Loamy soil & $?$ & $?$ & $?$ & $?$ \\
\hline Derouard et al. 1997 & $?$ & Sandy soil & $0.11 \%$ & $5 \%$ & $87 \%$ & $0.91 \%$ \\
\hline $\begin{array}{l}\text { Devliegher and } \\
\text { Verstraete } 1997\end{array}$ & Ardoyne & Sandy soil & $?$ & $?$ & $?$ & $0.9 \%$ \\
\hline Daube et al. 1997 & $\begin{array}{l}\text { Xerosol, Palexeralf, } \\
\text { wiesenboden }\end{array}$ & $\begin{array}{l}\text { Sandy soil, loamy } \\
\text { soil and clayey soil }\end{array}$ & $?$ & $?$ & $?$ & $?$ \\
\hline Eisenhauer et al. 2009 & Eutric Fluvisol & Loam soil & $0.3 \%$ & $?$ & $?$ & $4.6 \%$ \\
\hline Eisenhauer et al. 2008 & Gleyic cambisol & Silty soil & $?$ & $22 \%$ & $9 \%$ & $1.1 \%$ \\
\hline $\begin{array}{l}\text { Eisenhauer and Scheu } \\
\text { 2008a }\end{array}$ & Eutric Fluvisol & Loam soil & $0.3 \%$ & $?$ & $?$ & $4.6 \%$ \\
\hline $\begin{array}{l}\text { Eisenhauer and Scheu } \\
\text { 2008b }\end{array}$ & Eutric Fluvisol & Loam soil & $0.3 \%$ & $?$ & ? & $4.6 \%$ \\
\hline $\begin{array}{l}\text { Eriksen-Hamel and } \\
\text { Whalen } 2007\end{array}$ & Typic endoquent & Sandy loam soil & $?$ & $12 \%$ & $58 \%$ & $2.45 \%$ \\
\hline $\begin{array}{l}\text { Eriksen-Hamel and } \\
\text { Whalen } 2008\end{array}$ & Typic endoquent & Loam soil & $?$ & $?$ & $?$ & $5.6 \%-13.3 \%$ \\
\hline Fraser et al. 2003 & Udic dystrochrept & Silt loam soil & $0.2 \%$ & ? & $?$ & $2.6 \%$ \\
\hline Gilot 1997 & Ferralsol & Sandy soil & $0.44 \%-0.59 \%$ & $6 \%-10 \%$ & $>75 \%$ & $>1 \%$ \\
\hline $\begin{array}{l}\text { Gilot-Villenave et al. } \\
1996\end{array}$ & Ferralsol & Sandy soil & $0.4 \%-1.2 \%$ & $2.4 \%-4.5 \%$ & $>80 \%$ & $0.28 \%-1.18 \%$ \\
\hline Hale et al. 2008 & Eutroboralf & Silty clay loam soil & $?$ & $?$ & $?$ & $?$ \\
\hline Hale et al. 2006 & Eutroboralf & $?$ & $?$ & $?$ & $?$ & $?$ \\
\hline Hopp and Slatter 1948 & $?$ & Clayey soil & $?$ & $70 \%$ & $16 \%$ & $?$ \\
\hline Kreuzer et al. 2004 & $?$ & $?$ & $<0.1 \%$ & $?$ & $?$ & $1.8 \%$ \\
\hline Taossi et al. 2009a & Cambisol & Sandy soil & $0.12 \%$ & $6.9 \%$ & $74 \%$ & $1.47 \%$ \\
\hline Taossi et al. 2009b & $\begin{array}{l}\text { Cambisol and } \\
\text { leptosol }\end{array}$ & $\begin{array}{l}\text { Sandy soil and } \\
\text { clayey soil }\end{array}$ & $0.12 \% ; 0.46 \%$ & $6.9 \% ; 34.4 \%$ & $74 \% ; 27 \%$ & $1.47 \% ; 5.67 \%$ \\
\hline Milcu et al. 2006 & Eutric Fluvisol & Loam soil & $0.3 \%$ & $?$ & $?$ & $4.6 \%$ \\
\hline Milleret et al. 2009 & Anthrosol & $\begin{array}{l}\text { Sandy soil }+ \\
\text { compost }\end{array}$ & $?$ & $26.7 \%$ & $45.3 \%$ & $?$ \\
\hline Newington et al. 2004 & $?$ & $\begin{array}{l}\text { Sandy loam }+ \\
\text { aquatic compost }+ \\
\text { leaf mulch }\end{array}$ & $<0.01 \%$ & $?$ & ? & $?$ \\
\hline $\begin{array}{l}\text { Ortiz-Ceballos et al. } \\
2007 \mathrm{a}\end{array}$ & Fluvisol & Silty clay loam soil & $0.25 \%$ & $26.8 \%$ & $41.5 \%$ & $?$ \\
\hline $\begin{array}{l}\text { Ortiz-Ceballos et al. } \\
2007 b\end{array}$ & Fluvisol & Silty clay loam soil & $0.25 \%$ & $26.8 \%$ & $41.5 \%$ & ? \\
\hline Partsch et al. 2006 & Eutric Fluvisol & Loam soil & $0.3 \%$ & $?$ & $15 \%$ & $4.6 \%$ \\
\hline Pashanasi et al. 1996 & Paleudult & Sandy loam soil & $?$ & $23 \%$ & $55 \%$ & $?$ \\
\hline Patron et al. 1999 & Inceptisol & Sandy soil & $0.08 \%$ & $11 \%$ & $82 \%$ & $0.85 \%$ \\
\hline Poveda et al. 2005a & $?$ & $?$ & $?$ & $?$ & $?$ & $?$ \\
\hline Poveda et al. 2005b & $?$ & $?$ & $?$ & $?$ & $?$ & $?$ \\
\hline Schmidt and Curry 1999 & Podzol & $\begin{array}{l}\text { Loam to clay loam } \\
\text { soil }\end{array}$ & $0.18 \%$ & $19 \%$ & $47 \%$ & $1.88 \%$ \\
\hline $\begin{array}{l}\text { Stephens and Davoren } \\
1995\end{array}$ & Calcic Natrixeralf & Calcic soil & $?$ & $?$ & $?$ & $1.5 \%$ \\
\hline
\end{tabular}


TABle 1: Continued.

\begin{tabular}{|c|c|c|c|c|c|c|}
\hline References & Soil classification & Soil texture & $\mathrm{N}$ total & Clay & Sand & C Total \\
\hline $\begin{array}{l}\text { Stephens and Davoren } \\
1997\end{array}$ & Calcic Natrixeralf & Calcic soil & $?$ & $?$ & $?$ & $?$ \\
\hline Thompson et al. 1993 & $?$ & Loam soil & $?$ & $?$ & $?$ & $?$ \\
\hline $\begin{array}{l}\text { Welke and Parkinson } \\
2003\end{array}$ & $\begin{array}{l}\text { Dystric brunisols, } \\
\text { grey-brown } \\
\text { luvisols }\end{array}$ & Sandy loam soil & $0.1 \%-1.07 \%$ & $?$ & $?$ & $\begin{array}{c}21.63 \%- \\
43.73 \%\end{array}$ \\
\hline Wurst et al. 2008 & $?$ & $\begin{array}{l}\text { Loamy sandy } \\
\text { mineral soil }\end{array}$ & $0.13 \%$ & $?$ & $?$ & $2.1 \%$ \\
\hline Wurst et al. 2005 & Cambisol & Loam soil & $0.087 \%$ & $?$ & $?$ & $1.58 \%$ \\
\hline Wurst et al. 2003 & $?$ & Loam soil & $0.087 \%$ & $?$ & $?$ & $1.58 \%$ \\
\hline Zaller and Arnone 1999 & Rendzina & Calcareous soil & $?$ & $?$ & $?$ & $?$ \\
\hline
\end{tabular}

that the capacity of earthworms to alleviate this limiting factor can be tested. This allows testing main mechanisms through which (see introduction) earthworms affect plant growth in particular conditions. Such experiments could be repeated in soils differing by only one property to determine how this property modulates the strength of each of these mechanisms. For example, previous experimental studies conducted in greenhouse conditions [27, 30] and using sandy soil have showed that earthworms enhanced the tolerance of plants to nematodes. This kind of study should be carried out using sandy and clayey soil in the same experiment to test whether soils properties change the strength and direction of this earthworm effect.

While comparing earthworm effect in different soils differing by only one parameter is easy, this is not likely to allow disentangling all factors because soil properties are often correlated. Clay soils are generally rich in organic matter. A solution would be to directly manipulate soil properties. Hence, it would be possible to add, for example, clay, sand, organic matter, or mineral nutrients to a soil. We would then study the effect of a gradient in clay, sand, organic matter, or mineral nutrient on earthworm-induced effect. In the same vein, earthworm effect on the nutrient inputoutput balance of ecosystems should determine the longterm effect of earthworm on plant primary production [31]. Thus, comparing earthworm effects in different soils could also allow measuring their effects on nutrient leaching in these different soils and to identify the type of soil in which nutrients made available are leached and in which other it remains in the superficial soil layers. This is important to determine the long-term effect of earthworm-soil type interaction on plant growth. Another possibility would be to conduct meta-analyses to take advantage of the numerous studies already published on the issue. We give below a first example of such meta-analyses.

\section{Example of Meta-Analysis}

We used the results of 25 experiments (Table 1) to perform a meta-analysis and calculate the effect size of earthworms influence on plant growth in different soil types with

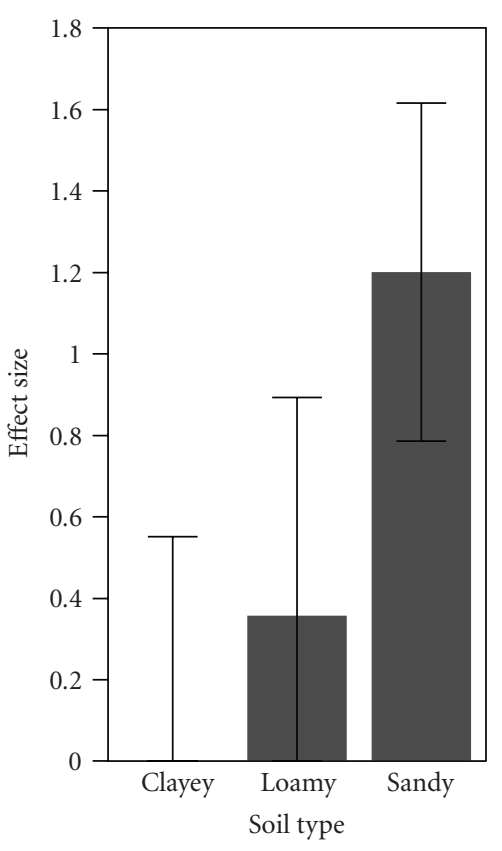

Figure 1: Effect size of earthworm effects on plant growth based on results of 25 experiments presented in Table 1 . Mean effect size calculated as $[M 1-M 2] / \sigma$ with $M 1$ : mean plant biomass in the presence of earthworms, $M 2$ : mean plant biomass without earthworm, and $\sigma$ : standard deviation without earthworm. $P=.02$

contrasting texture properties (sandy, clayey, or loamy soil). The effect size was computed as $(M 1-M 2) / \sigma$, with $M 1$ : mean plant biomass in the presence of earthworms, $M 2$ : mean plant biomass without earthworm, and $\sigma$ : standard deviation without earthworm [32]. An ANOVA was then used to test for the effect of soil texture on the effect size, that is, on the magnitude of earthworm impact on plant biomass. This shows that soil texture influences significantly earthworm impact on plant growth $\left(r^{2}=0.11\right.$ and $\left.P=.02\right)$. LS mean comparisons show that the effect size was in sandy and loamy soils, respectively, 60- and 17.5- fold higher than in clayey soil. The result highlights a strong positive effect size in sandy soil and a weakly negative effect in clayey soil (Figure 1). 
This result supports the assertion of Brown et al. [2] that positive effects of earthworms on plant growth are more pronounced in sandy soils (generally nutrient-poor soils) that in clayey soils (generally nutrient-rich soil). However, as showed in Table 1 most studies used sandy soils while only few studies have used clayey ones. We thus need to release this bias by developing more studies for clayey soil. Nevertheless, our meta-analysis is the first formal test of the influence of soil properties on earthworm effect on plant growth.

\section{Conclusion}

Although the majority of authors provided detailed data on soil characteristics, this basic information was not available in all studies in earthworm impacts on plant production (Table 1). Further studies should pay attention to providing a standardized description of soil characteristics, which would thus be available for meta-analyses on earthwormsplants studies. For example, data on soil texture (sand and clay percentage), total $\mathrm{C}$, total $\mathrm{N}$ content, $\mathrm{NH}_{4}{ }^{+}$, and $\mathrm{NO}_{3}{ }^{-}$should be systematically published. Because such information, is not always given (see Table 1), we have only compared the effect of wide texture classes on earthworm effect. Finally, we have shown that these texture classes only explain $11 \%$ of the variations in effect sizes. This is probably due to a variety of other factors that we have not taken into account: soil properties mentioned above but also earthworm species (or its functional group) and plant species (or its functional group), and so forth [2, 3]. Gathering more studies on earthworm effects on plant growth and documenting for each of these studies all these factors would allow disentangling, through a unique metaanalysis statistical model, the respective effect of all these factors on earthworm-induced effect on plant growth, as well as interactions between these factors. This kind of general and systematic approach is required to derive general results on soil ecology and to develop the theoretical background needed to base soil ecology on solid bases [33].

Taken together, while a given earthworm species could have positive effects in a soil, it could have negative effects in another soil. To restore soil fertility or to enhance the sustainability of crop production [14], the right earthworm species has indeed to be chosen according to soil properties and crop type. Developing applications based on the use of earthworms would thus also require implementing the general meta-analysis (as suggested above) and the subsequent development of a general and comprehensive framework on earthworm-induced effect on plant growth that is so far missing.

\section{References}

[1] C. A. Edwards, Ed., Earthworm Ecology, CRC Press, Boca Raton, Fla, USA, 2004.

[2] G. G. Brown, C. A. Edwards, and L. Brussaard, "How earthworms effect plant growth: burrowing into the mechanisms," in Earthworm Ecology, C. A. Edwards, Ed., pp. 13-49, 2004.

[3] S. Scheu, "Effects of earthworms on plant growth: patterns and perspectives," Pedobiologia, vol. 47, no. 5-6, pp. 846-856, 2003.
[4] M. Blouin, S. Barot, and P. Lavelle, "Earthworms (Millsonia anomala, Megascolecidae) do not increase rice growth through enhanced nitrogen mineralization," Soil Biology and Biochemistry, vol. 38, no. 8, pp. 2063-2068, 2006.

[5] B. M. Doube, P. M. L. Williams, and P. J. Willmott, "The influence of two species of earthworm (Aporrectodea trapezoides and Aporrectoedea rosea) on the growth of wheat, barley and faba beans in three soil types in the greenhouse," Soil Biology and Biochemistry, vol. 29, no. 3-4, pp. 503-509, 1997.

[6] S. Wurst and T. H. Jones, "Indirect effects of earthworms (Aporrectodea caliginosa) on an above-ground tritrophic interaction," Pedobiologia, vol. 47, no. 1, pp. 91-97, 2003.

[7] K.-R. Laossi, A. Ginot, D. C. Noguera, M. Blouin, and S. Barot, "Earthworm effects on plant growth do not necessarily decrease with soil fertility," Plant and Soil, vol. 328, no. 1-2, pp. 109-118, 2010.

[8] P. J. Bohlen, D. M. Pelletier, P. M. Groffman, T. J. Fahey, and M. C. Fisk, "Influence of earthworm invasion on redistribution and retention of soil carbon and nitrogen in northern temperate forests," Ecosystems, vol. 7, no. 1, pp. 13-27, 2004.

[9] P. J. Bohlen, C. A. Edwards, Q. Zhang, R. W. Parmelee, and M. Allen, "Indirect effects of earthworms on microbial assimilation of labile carbon," Applied Soil Ecology, vol. 20, no. 3, pp. 255-261, 2002.

[10] A. Martin, A. Mariotti, J. Balesdent, and P. Lavelle, "Soil organic matter assimilation by a geophagous tropical earthworm based on $\delta^{13} \mathrm{C}$ measurements," Ecology, vol. 73, no. 1, pp. 118-128, 1992.

[11] J. Domínguez, P. J. Bohlen, and R. W. Parmelee, "Earthworms increase nitrogen leaching to greater soil depths in row crop agroecosystems," Ecosystems, vol. 7, no. 6, pp. 672-685, 2004.

[12] P. Jouquet, F. Bernard-Reversat, N. Bottinelli, et al., "Influence of changes in land use and earthworm activities on carbon and nitrogen dynamics in a steepland ecosystem in Northern Vietnam," Biology and Fertility of Soils, vol. 44, no. 1, pp. 6977, 2007.

[13] M. B. Bouché, "Stratégies lombriciennes," in Soil Organisms as Components of Ecosystems, U. Lohm and T. Persson, Eds., Ecological Bulletins 25, pp. 122-132, Stockholm, Sweden, 1977.

[14] P. Lavelle, I. Barois, E. Blanchart, et al., "Earthworms as a resource in tropical agroesosystems," Nature and Resources, vol. 34, pp. 26-40, 1998.

[15] K.-R. Laossi, D.-C. Noguera, and S. Barot, "Earthwormmediated maternal effects on seed germination and seedling growth in three annual plants," Soil Biology and Biochemistry, vol. 42, no. 2, pp. 319-323, 2010.

[16] K.-R. Laossi, Effet des vers de terre sur les plantes : du fonctionnement individuel à la structure des communautés végétales, Ph.D. thesis, Université Pierre et Marie Curie, Paris, France, 2009.

[17] K.-R. Laossi, D. C. Noguera, J. Mathieu, M. Blouin, and S. Barot, "Effects of an endogeic and an anecic earthworm on the competition between four annual plants and their relative fecundity," Soil Biology and Biochemistry, vol. 41, no. 8, pp. 1668-1673, 2009.

[18] P. Jouquet, J. Dauber, J. Lagerlöf, P. Lavelle, and M. Lepage, "Soil invertebrates as ecosystem engineers: intended and accidental effects on soil and feedback loops," Applied Soil Ecology, vol. 32, no. 2, pp. 153-164, 2006.

[19] M. Blouin, P. Lavelle, and D. Laffray, "Drought stress in rice (Oryza sativa L.) is enhanced in the presence of the compacting earthworm Millsonia anomala," Environmental and Experimental Botany, vol. 60, no. 3, pp. 352-359, 2007. 
[20] P. Lavelle, T. Decaëns, M. Aubert, et al., "Soil invertebrates and ecosystem services," European Journal of Soil Biology, vol. 42, supplement 1, pp. S3-S15, 2006.

[21] A. Kretzschmar, "Effects of earthworms on soil organization," in Earthworm Ecology, C. A. Edwards, Ed., vol. 1, pp. 201-210, 2nd edition, 2004.

[22] A. Chauvel, M. Grimaldi, E. Barros, et al., "Pasture damage by an Amazonian earthworm," Nature, vol. 398, no. 6722, pp. 32-33, 1999.

[23] P. Lavelle and A. Spain, Soil Ecology, Kluwer Academic Publishers, Dordrecht, The Netherlands, 2001.

[24] L. Ping and W. Boland, "Signals from the underground: bacterial volatiles promote growth in Arabidopsis," Trends in Plant Science, vol. 9, no. 6, pp. 263-266, 2004.

[25] P. F. Hendrix, A. C. Peterson, M. H. Beare, and D. C. Coleman, "Long-term effects of earthworms on microbial biomass nitrogen in coarse and fine textured soils," Applied Soil Ecology, vol. 9, no. 1-3, pp. 375-380, 1998.

[26] Q. Huang, W. Liang, and P. Cai, "Adsorption, desorption and activities of acid phosphatase on various colloidal particles from an Ultisol," Colloids and Surfaces B, vol. 45, no. 3-4, pp. 209-214, 2005.

[27] M. Blouin, Y. Zuily-Fodil, A.-T. Pham-Thi, et al., "Belowground organism activities effect plant aboveground phenotype, including plant tolerance to parasites," Ecology Letters, vol. 8, pp. 202-208, 2005.

[28] P. M. Stephens and C. W. Davoren, "Influence of the earthworms Aporrectodea trapezoides and A. Rosea on the disease severity of Rhizoctonia solani on subterranean clover and ryegrass," Soil Biology and Biochemistry, vol. 29, no. 3-4, pp. 511-516, 1997.

[29] B. M. Doube, M. H. Ryder, C. W. Davoren, and P. M. Stephens, "Enhanced root nodulation of subterranean clover (Trifolium subterraneum) by Rhizobium leguminosarum biovar trifolii in the presence of the earthworm Aporrectodea trapezoides (Lumbricidae)," Biology and Fertility of Soils, vol. 18, no. 3, pp. 169-174, 1994.

[30] S. Wurst, B. Allema, H. Duyts, and W. H. van der Putten, "Earthworms counterbalance the negative effect of microorganisms on plant diversity and enhance the tolerance of grasses to nematodes," Oikos, vol. 117, no. 5, pp. 711-718, 2008.

[31] S. Barot, A. Ugolini, and F. B. Brikci, "Nutrient cycling efficiency explains the long-term effect of ecosystem engineers on primary production," Functional Ecology, vol. 21, no. 1, pp. $1-10,2007$.

[32] L. V. Hedges and I. Olkin, Statistical Methods for MetaAnalysis, Academic Press, New York, NY, USA, 1985.

[33] S. Barot, M. Blouin, S. Fontaine, P. Jouquet, J.-C. Lata, and J. Mathieu, "A tale of four stories: soil ecology, theory, evolution and the publication system," Plos One, vol. 2, article e12, 2007. 

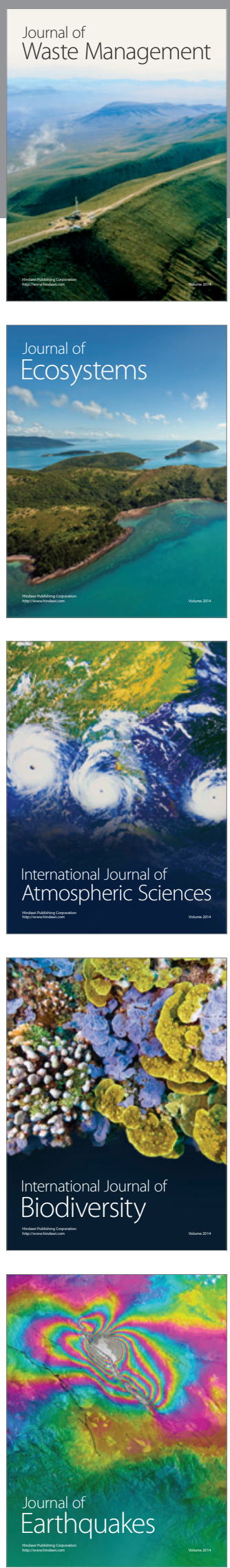
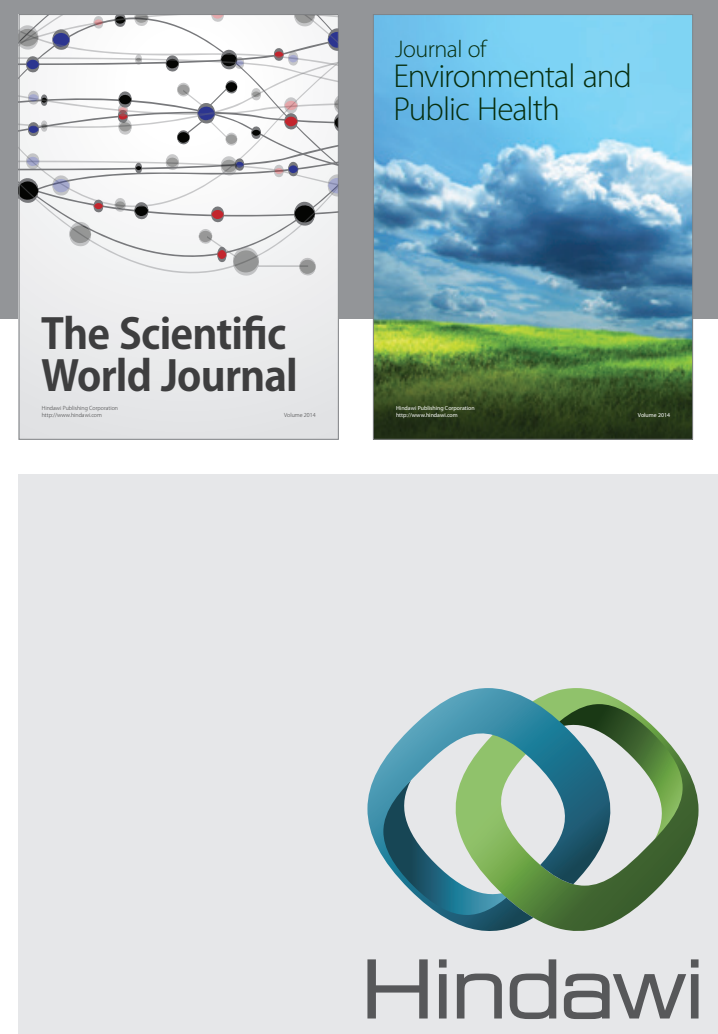

Submit your manuscripts at

http://www.hindawi.com
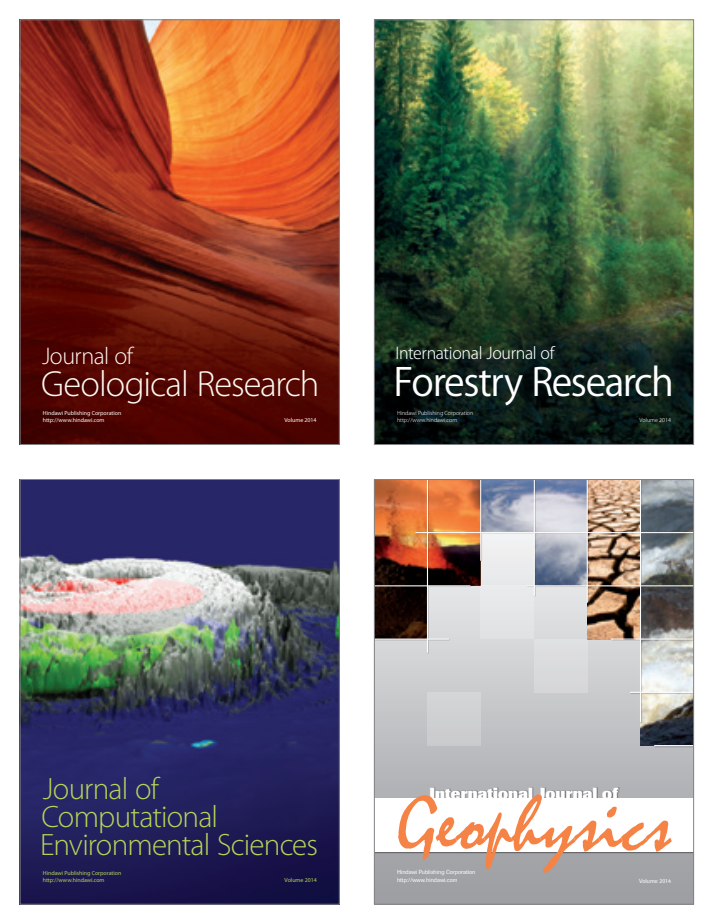
